\title{
Experimental poisoning by Crotalaria lanceolata and Crotalaria pallida seeds in broilers ${ }^{1}$
}

\author{
Thaiza Savaris $^{2}$ (D), Claudia P. Biffi ${ }^{3}$ (D), Daiane Ogliari ${ }^{3}$, \\ Nathalia Wicpolt ${ }^{3}$, Franciéli Adriane Molossi ${ }^{3}$ (D), Elaine Melchioretto ${ }^{3}$, \\ Dale Gardner ${ }^{4}$ and Aldo Gava ${ }^{3 *}$ (D)
}

\begin{abstract}
Savaris T., Biffi C.P., Ogliari D., Wicpolt N., Molossi F.A., Melchioretto E., Gardner D. \& Gava A. 2019. Experimental poisoning by Crotalaria lanceolata and Crotalaria pallida seeds in broilers. Pesquisa Veterinária Brasileira 39(11):863-869. Laboratório de Patologia Animal, Centro de Ciências Agroveterinárias, Universidade do Estado de Santa Catarina, Av. Luiz de Camões 2090, Conta Dinheiro, Lages, SC 88520-000, Brazil. E-mail: aldo.gava@udesc.br

Crotalaria lanceolata E. Mey. and Crotalaria pallida Aiton. are leguminous plants of family Fabaceae found in most of the Brazilian territory. They were initially used as green manure and due their easy spread they are currently considered weeds in crops. Soybean and corn contamination can occur through the mechanical harvesting of these grains along with seeds of the Crotalaria species, which end up in the formulation of feed for production animals. Crotalaria spp. genus has toxic pyrrolizidine alkaloids (PA). Most plant species belonging to this genus can cause acute or chronic liver injury. In a first stage, one-day old broilers were divided into three groups: Group A (C. pallida seeds), Group B (C. lanceolata seeds), and Group C (Control). Groups A and B were divided into five subgroups, each with eight broilers, which received the following doses of the respective seeds in feed as of the $7^{\text {th }}$ day of age: daily doses of $0.4 \%, 0.8 \%$ and $2.5 \%$, and single doses of $15 \%$ and $25 \%$. Four broilers in each study group were euthanized at 28 days of age - completing 21 days of seed consumption, and the four remaining broilers were euthanized at 42 days of age - completing 35 days of seed consumption. In a second stage, experiments were conducted using seeds of both the aforementioned plants with 28-day old broilers. These were divided into three groups of four animals each: Group D (C. pallida seeds) and Group E (C. lanceolata seeds), which received the respective seeds at daily doses of $1 \%$ and $2 \%$ in feed for 20 days, and Group F (Control). These broilers were euthanized when they were 80 days old. C. lanceolata seeds showed higher toxicity to broilers than $C$. pallida seeds, both supplied as of the $7^{\text {th }}$ day of life. Clinical signs included inappetence, ruffled feathers, and brown diarrhea. The following gross lesions were observed: subcutaneous edema, ascites, hydropericardium, yellowish liver with hypertrophy or atrophy and enhanced lobular pattern, and distended gallbladder. Histologic lesions present in all birds in varying degrees were characterized by tumefaction and vacuolar degeneration of hepatocytes. The following clinical conditions and gross lesions were observed in the broilers: hepatocyte megalocytosis and karyomegaly, slight biliary epithelial hyperplasia, eosinophilic spheroids, and nuclear invagination with loss of hepatocyte cord architecture.
\end{abstract}

INDEX TERMS: Experimental poisoning, Crotalaria lanceolata E. Mey., Crotalaria pallida Aiton., Fabaceae, hepatotoxic plants, pyrrolizidine alkaloids, Crotalaria sp., broilers, toxic plants, poisoning, toxicoses.

${ }^{1}$ Received on January 23, 2019.

Accepted for publication on April 1, 2019.

Part of the Master's Thesis of the first author, concluded on 2016.

${ }^{2}$ Universidade do Estado de Santa Catarina (UDESC), Av. Luiz de Camões 2090, Conta Dinheiro, Lages, SC 88520-000, Brazil. ${ }^{3}$ Laboratório de Patologia Animal, Centro de Ciências Agroveterinárias
(CAV), Universidade do Estado de Santa Catarina (UDESC), Av. Luiz de
Camões 2090, Bairro Conta Dinheiro, Lages, SC 88520-000. ${ }^{*}$ Corresponding
author: aldo.gava@udesc.br
(A Poisonous Plant Research Laboratory, Agricultural Research Service
(ARS), United States Department of Agriculture (USDA), Logan, Utah, USA. 
RESUMO.- [Intoxicação experimental pelas sementes de Crotalaria lanceolata E. Mey. e Crotalaria pallida Aiton. em frangos de corte.] Crotalaria lanceolata E. Mey. e Crotalaria pallida Aiton. são leguminosas da família Fabaceae presentes na maioria do território brasileiro. Inicialmente foram utilizadas como adubação verde e devido sua fácil disseminação são consideradas invasoras de culturas. Através da colheita mecanizada da soja e milho pode ocorrer a contaminação destes grãos com sementes dessas espécies e entrar na formulação de ração para animais de produção. 0 gênero Crotalaria spp. possui alcaloides pirrolizidínicos de ação tóxica. A maioria das espécies desse gênero causam lesões hepáticas, com evolução aguda, ou, crônica. Frangos de corte de um dia de vida foram divididos em três grupos: Grupo A (sementes de C. pallida - doses diárias de 0,4\%, 0,8\%,2,5\% e doses únicas de $15 \%$ e $25 \%$ ), Grupo B (sementes de C. lanceolata - doses diárias de $0,4 \%, 0,8 \%, 2,5 \%$ e doses únicas de $15 \%$ e $25 \%$ ) e Grupo C (Controle). Os Grupos A e B foram divididos em cinco subgrupos, com oito frangos cada, que a partir do sétimo dia de vida, receberam as doses estabelecidas. Quatro frangos de cada grupo foram sacrificados aos 28 dias, e os quatro restantes aos 42 dias de vida. Também foram conduzidos experimentos com as sementes dessas duas plantas com aves de 28 dias, as quais foram divididas em três grupos: Grupo D (C. pallida doses de $1 \%$ e $2 \%$ diariamente, durante vinte dias), Grupo E (C. lanceolata - doses de 1\% e $2 \%$ diariamente, durante vinte dias) e Grupo F (Controle). Cada grupo composto por quatro aves. Estas aves foram sacrificadas ao completarem 80 dias de vida. Sementes de $C$. lanceolata demonstraram maior toxicidade para frangos de corte do que sementes de C. pallida. Os sinais clínicos foram inapetência, penas arrepiadas e diarreia acastanhada. Na macroscopia observou-se edema subcutâneo, ascite, hidropericárdio, fígado de coloração amarelada com hipertrofia e, ou, atrofia, evidenciação do padrão lobular e vesícula biliar distendida. As lesões histológicas presentes em todas as aves, em diferentes graus caracterizaram-se por tumefação e degeneração vacuolar de hepatócitos. Nas aves que manifestaram alterações clínicas e lesões macroscópicas, havia megalocitose, cariomegalia, hiperplasia do epitélio biliar, leve, esferoides eosinofílicos e invaginação nuclear com perda da arquitetura dos cordões de hepatócitos.

TERMOS DE INDEXAÇÃO: Intoxicação experimental, Crotalaria lanceolata E. Mey., Crotalaria pallida Aiton., Fabaceae, plantas hepatotóxicas, alcaloides pirrolizidínicos, intoxicação por Crotalaria sp., frangos de corte, toxicoses.

\section{INTRODUCTION}

Genus Crotalaria spp., family Fabaceae is distributed throughout the Brazilian territory, with 42 known species (Flores 2015, Garcia et al. 2013). Plants of this genus have pyrrolizidine alkaloids (Williams \& Molyneux 1987, Cheeke 1998) that are toxic not only to animals (Nobre et al. 2005), but also to humans (Wiedenfeld \& Edgar 2011, Fu et al. 2004). Although most of them cause acute or chronic liver injuries, some species can affect the respiratory system (Tokarnia et al. 2012). Pyrrolizidine alkaloid (PA) poisoning is a significant cause of mortality in Brazilian livestock (Lucena et al. 2010). Spontaneous outbreaks of poisoning have been reported in cattle by the leaves and seeds of Crotalaria pallida (Lemos et al. 1997), Crotalaria retusa (Nobre et al. 2004b) and Crotalaria incana
(Queiroz et al. 2013); in sheep by C. retusa leaves (Dantas et al. 2004, Riet-correa et al. 2011) and seeds (Anjos et al. 2010), and by C. pallida leaves (Borelli et al. 2016); in horses by seeds of Crotalaria juncea (Nobre et al. 1994) and C. retusa (Nobre et al. 2004a); in donkeys by seeds of $C$. juncea and C. retusa (Pessoa et al. 2013); in swine by Crotalaria spectabilis seeds (Ubiali et al. 2011). Experimental poisoning has been reproduced in cattle with leaves of $C$. pallida (Tokarnia \& Döbereiner 1982) and Crotalaria anagyroides (Tokarnia \& Döbereiner 1983) and with C. pallida seeds (Boghossian et al. 2007), and in swine with $C$. spectabilis seeds (Souza et al. 1997, Torres et al. 1997). Poisoning by Crotalaria lanceotala has not been reported in any animal species.

In Brazil, C. lanceolata and C. pallida are considered sub-spontaneous species (Garcia et al. 2013). The plants used in this study were found in fields cultivated in the municipality of São João do Sul, south coast of Santa Catarina state, and because these seeds are small, they can contaminate cereal grains during mechanized harvesting.

The objective of this study was to evaluate the toxicity of these two plant species, characterize the clinical and pathological conditions of the poisoning, and determine the toxic amounts for broilers.

\section{MATERIALS AND METHODS}

Crotalaria lanceolata E. Mey. and Crotalaria pallida Aiton. seeds were collected from January to June 2015 in the municipality of São João do Sul, southern coast of Santa Catarina state, Brazil. Plant samples were sent to the Department of Botany of the "Universidade do Estado de Santa Catarina" (UDESC) for identification. The seeds of both species were removed from the pods and dried in oven at $37^{\circ} \mathrm{C}$. The samples were weighed daily for three days until they reached constant weight. Samples of the dried seeds were sent to the Poisonous Plant Research Laboratory, Agricultural Research Service (ARS), United States Department of Agriculture (USDA), in Logan, Utah, USA, for analysis and quantification of the specific dosages of pyrrolizidine alkaloids (PA) contained in the seeds used in the experimental study.

Throughout the study period, the birds were inspected daily, having their behavior and feed intake evaluated. At pre-established ages, they were euthanized using the cervical dislocation method, approved by the Federal Council of Veterinary Medicine (CFMV), normative resolution no. 1000, and by the Animal Research and Ethics Committee, Center of Agricultural Sciences (CAV), UDESC under protocol no. 6169200716. For histologic examination, samples were collected from all organs, fixed in $10 \%$ buffered formalin, and routinely processed.

First stage of the experimental study. Eighty-eight Cobb broiler chickens were housed at one day of age and fed water and feed ad libitum until the $7^{\text {th }}$ day of life. As of this date, they were divided into three large groups: Group A, fed C. pallida seeds added to the ration at daily doses of $0.4 \%$ (A1), $0.8 \%$ (A2), 2.5\% (A3) and single doses of $15 \%$ (A4) and $25 \%$ (A5), totaling five subgroups with eight broilers each (40 birds in total); Group B, fed C. lanceolata seeds added to the ration at daily doses of $0.4 \%$ (B1), $0.8 \%$ (B2), $2.5 \%$ (B3) and single doses of 15\% (B4) and 25\% (B5), totaling five subgroups with eight broilers each ( 40 birds in total); Group C (Control), composed of with eight broiler chickens that received seed-free ration throughout the experiment. Four birds randomly chosen from each study group were euthanized for necropsy and 
sample collection for histopathologic examination at 28 and 42 days of age, respectively.

Second stage of the experimental study. Twenty Cobb broiler chickens were housed at 28 days of age and fed water and feed ad libitum throughout the experimental period, in addition to seeds of $C$. pallida and C. lanceolata until 50 days of age. The broilers were also separated into three groups as follows: Group D, fed C. pallida seeds added to the ration at daily doses of $1 \%$ (D1) and 2\% (D2) for 20 days, totaling two subgroups of four broilers each (8 birds in total); Group E, fed C. lanceolata seeds added to the ration at daily doses of $1 \%$ (E1) and $2 \%$ (E2) for twenty days, totaling two subgroups of four broilers each (8 birds in total); Group F (Control), composed of with four broiler chickens that received free-seed ration throughout the experiment. At 80 days of age, 30 days after the end of seed supply in the feed, all birds were euthanized for necropsy and material collection for histopathologic examination.

\section{RESULTS}

First stage of the experimental study. Crotalaria pallida: Only birds from Group A3 showed signs of inappetence and brownish diarrhea from the second week of the seed supply. There was no mortality in the groups. Macroscopic and microscopic lesions are shown in Table 1 and 2.

Crotalaria lanceolata: Groups B2 and B5 showed signs of inappetence, ruffled feathers, and brownish diarrhea from the second week of the seed supply. There was no mortality in the groups. Macroscopic and microscopic lesions are described in Table 3 and 4, respectively.

Table 1. Gross lesions observed in broilers euthanized at 28 and 42 days of age. Experimental poisoning by seeds of Crotalaria pallida, Group A (1, 2, 3, 4 and 5)

\begin{tabular}{|c|c|c|c|c|c|c|c|c|c|c|}
\hline \multirow{3}{*}{ Lesion } & \multicolumn{5}{|c|}{28 days } & \multicolumn{5}{|c|}{42 days } \\
\hline & \multicolumn{10}{|c|}{ Group } \\
\hline & $\begin{array}{c}\mathrm{A} 1 \\
0.4 \% \\
\end{array}$ & $\begin{array}{c}\mathrm{A} 2 \\
0.8 \% \\
\end{array}$ & $\begin{array}{c}\text { A3 } \\
2.5 \% \\
\end{array}$ & $\begin{array}{c}\mathrm{A} 4 \\
15 \% \mathrm{SD}^{*}\end{array}$ & $\begin{array}{c}\mathrm{A} 5 \\
25 \% \text { SD* }\end{array}$ & $\begin{array}{c}\text { A1 } \\
0.4 \% \\
\end{array}$ & $\begin{array}{c}\text { A2 } \\
0.8 \% \\
\end{array}$ & $\begin{array}{c}\text { A3 } \\
2.5 \% \\
\end{array}$ & $\begin{array}{c}\mathrm{A} 4 \\
15 \% \mathrm{SD}^{*}\end{array}$ & $\begin{array}{c}\mathrm{A} 5 \\
25 \% \mathrm{SD}^{*}\end{array}$ \\
\hline Ascites & - & - & - & - & - & $1 / 4$ & - & - & - & - \\
\hline Hydropericardium & $1 / 4$ & - & $2 / 4$ & - & - & - & $2 / 4$ & - & - & $1 / 4$ \\
\hline Distended gallbladder & $1 / 4$ & - & $1 / 4$ & - & - & - & $1 / 4$ & $1 / 4$ & - & $1 / 4$ \\
\hline Hepatic hypertrophy & $1 / 4$ & $1 / 4$ & $1 / 4$ & $1 / 4$ & $1 / 4$ & $1 / 4$ & $2 / 4$ & $1 / 4$ & $1 / 4$ & $2 / 4$ \\
\hline Subcutaneous edema & - & - & - & $1 / 4$ & - & $1 / 4$ & - & - & $1 / 4$ & - \\
\hline Enhanced lobular pattern liver & - & - & - & - & - & - & - & $1 / 4$ & - & - \\
\hline Yellowish liver & - & - & $1 / 4$ & $1 / 4$ & - & $1 / 4$ & - & - & - & - \\
\hline
\end{tabular}

* SD = single dose.

Table 2. Microscopic lesions observed in broilers euthanized at 28 and 42 days of age. Experimental poisoning by seeds of Crotalaria pallida, Group A (1, 2, 3, 4 and 5)

\begin{tabular}{|c|c|c|c|c|c|c|c|c|c|c|}
\hline \multirow{3}{*}{ Lesion } & \multicolumn{5}{|c|}{28 days } & \multicolumn{5}{|c|}{42 days } \\
\hline & \multicolumn{10}{|c|}{ Group } \\
\hline & $\begin{array}{c}\mathrm{A} 1 \\
0.4 \% \\
\end{array}$ & $\begin{array}{c}\mathrm{A} 2 \\
0.8 \% \\
\end{array}$ & $\begin{array}{c}\text { A3 } \\
2.5 \% \\
\end{array}$ & $\begin{array}{c}\mathrm{A} 4 \\
15 \% \mathrm{SD}^{*}\end{array}$ & $\begin{array}{c}\mathrm{A} 5 \\
25 \% \mathrm{SD}^{*}\end{array}$ & $\begin{array}{c}\mathrm{A} 1 \\
0.4 \% \\
\end{array}$ & $\begin{array}{c}\mathrm{A} 2 \\
0.8 \% \\
\end{array}$ & $\begin{array}{c}\text { A3 } \\
2.5 \% \\
\end{array}$ & $\begin{array}{c}\mathrm{A} 4 \\
15 \% \mathrm{SD}^{*}\end{array}$ & $\begin{array}{c}\mathrm{A} 5 \\
25 \% \mathrm{SD}^{*}\end{array}$ \\
\hline Pulmonary edema & - & - & - & - & - & - & - & - & - & - \\
\hline Vacuolar hepatocyte degeneration & - & - & - & - & - & - & + & + & - & - \\
\hline Hepatocyte megalocytosis & - & - & - & - & - & - & - & - & - & - \\
\hline Hepatocyte karyomegaly & - & - & - & - & - & - & + & ++ & - & + \\
\hline Hepatocyte swelling & - & - & - & - & - & - & - & + & - & + \\
\hline Nuclear hepatocyte invagination & - & - & - & - & - & - & - & - & - & - \\
\hline
\end{tabular}

* SD = single dose; + mild, ++ moderate, +++ severe.

Table 3. Gross lesions observed in broilers euthanized at 28 and 42 days of age. Experimental poisoning by Crotalaria lanceolata seeds, Group B (1, 2, 3, 4 and 5)

\begin{tabular}{|c|c|c|c|c|c|c|c|c|c|c|}
\hline \multirow{3}{*}{ Lesions } & \multicolumn{5}{|c|}{28 days } & \multicolumn{5}{|c|}{42 days } \\
\hline & \multicolumn{10}{|c|}{ Group } \\
\hline & $\begin{array}{c}\text { B1 } \\
0.4 \% \\
\end{array}$ & $\begin{array}{c}\text { B2 } \\
0.8 \% \\
\end{array}$ & $\begin{array}{c}\text { B3 } \\
2.5 \% \\
\end{array}$ & $\begin{array}{c}\text { B4 } \\
15 \% \text { SD* }\end{array}$ & $\begin{array}{c}\text { B5 } \\
25 \% \mathrm{SD}^{*}\end{array}$ & $\begin{array}{c}\text { B1 } \\
0.4 \% \\
\end{array}$ & $\begin{array}{c}\text { B2 } \\
0.8 \% \\
\end{array}$ & $\begin{array}{c}\text { B3 } \\
2.5 \% \\
\end{array}$ & $\begin{array}{c}\text { B4 } \\
15 \% \mathrm{SD}^{*}\end{array}$ & $\begin{array}{c}\text { B5 } \\
25 \% \text { SD* }^{*}\end{array}$ \\
\hline Ascites & - & - & - & - & - & - & - & - & $1 / 4$ & - \\
\hline Hydropericardium & - & $1 / 4$ & $1 / 4$ & $1 / 4$ & - & - & $1 / 4$ & $2 / 4$ & $2 / 4$ & $3 / 4$ \\
\hline Distended gallbladder & - & - & - & - & $1 / 4$ & - & $1 / 4$ & $1 / 4$ & $1 / 4$ & - \\
\hline Hepatic hypertrophy & $2 / 4$ & - & $2 / 4$ & $2 / 4$ & $1 / 4$ & $2 / 4$ & - & $1 / 4$ & - & $3 / 4$ \\
\hline Subcutaneous edema & - & - & $2 / 4$ & - & $1 / 4$ & - & - & $2 / 4$ & - & $2 / 4$ \\
\hline Enhanced lobular pattern liver & - & - & - & $1 / 4$ & - & - & - & - & - & - \\
\hline Yellowish liver & - & $1 / 4$ & - & - & $1 / 4$ & $2 / 4$ & - & - & $2 / 4$ & - \\
\hline
\end{tabular}

* SD = single dose. 
Table 4. Microscopic lesions observed in broilers euthanized at 28 and 42 days of age. Experimental poisoning by Crotalaria lanceolata seeds, Group B (1, 2, 3, 4 and 5)

\begin{tabular}{|c|c|c|c|c|c|c|c|c|c|c|}
\hline \multirow{3}{*}{ Lesions } & \multicolumn{5}{|c|}{28 days } & \multicolumn{5}{|c|}{42 days } \\
\hline & \multicolumn{10}{|c|}{ Group } \\
\hline & $\begin{array}{c}\text { B1 } \\
0.4 \% \\
\end{array}$ & $\begin{array}{c}\text { B2 } \\
0.8 \% \\
\end{array}$ & $\begin{array}{c}\text { B3 } \\
2.5 \% \\
\end{array}$ & $\begin{array}{c}\text { B4 } \\
15 \% \mathrm{SD}^{*}\end{array}$ & $\begin{array}{c}\text { B5 } \\
25 \% \mathrm{SD}^{*}\end{array}$ & $\begin{array}{c}\text { B1 } \\
0.4 \% \\
\end{array}$ & $\begin{array}{c}\text { B2 } \\
0.8 \% \\
\end{array}$ & $\begin{array}{c}\text { B3 } \\
2.5 \% \\
\end{array}$ & $\begin{array}{c}\text { B4 } \\
15 \% \mathrm{SD}^{*}\end{array}$ & $\begin{array}{c}\text { B5 } \\
25 \% \mathrm{SD}^{*}\end{array}$ \\
\hline Pulmonary edema & - & - & - & - & - & - & - & - & - & - \\
\hline Vacuolar hepatocytes degeneration & + & - & + & + & + & - & - & + & - & + \\
\hline Hepatocyte megalocytosis & + & + & - & - & ++ & - & - & + & - & - \\
\hline Hepatocyte karyomegaly & + & + & + & + & ++ & + & + & + & - & + \\
\hline Hepatocyte swelling & + & + & - & + & ++ & + & + & + & - & + \\
\hline Nuclear hepatocyte invagination & - & - & + & + & + & - & + & - & - & - \\
\hline
\end{tabular}

* SD = single dose $;+$ mild,++ moderate, +++ severe.

Table 5. Gross lesions observed in broilers euthanized at 80 days. Experimental poisoning by Crotalaria pallida and Crotalaria lanceolata seeds, 1\% and 2\% in the diet, Group D (1 and 2) and Group E (1 and 2)

\begin{tabular}{|c|c|c|c|c|}
\hline \multirow[b]{2}{*}{ Lesions } & \multicolumn{4}{|c|}{ Group } \\
\hline & $\begin{array}{c}\mathrm{D} 1 \\
1 \% \text { C. pallida }\end{array}$ & $\begin{array}{c}\text { D2 } \\
2 \% \text { C. pallida }\end{array}$ & $\begin{array}{c}\mathrm{E} 1 \\
1 \% \text { C. lanceolata }\end{array}$ & $\begin{array}{c}\mathrm{E} 2 \\
2 \% \text { C. lanceolata }\end{array}$ \\
\hline Ascites & - & - & $1 / 4$ & $1 / 4$ \\
\hline Hydropericardium & - & - & $2 / 4$ & $2 / 4$ \\
\hline Distended gallbladder & - & $2 / 4$ & $1 / 4$ & - \\
\hline Hepatic hypertrophy & - & - & $1 / 4$ & $2 / 4$ \\
\hline Hepatic atrophy & - & $4 / 4$ & $1 / 4$ & $1 / 4$ \\
\hline Pulmonary edema & - & - & $1 / 4$ & $1 / 4$ \\
\hline Enhanced lobular pattern liver & - & $1 / 4$ & - & - \\
\hline Yellowish liver & - & $1 / 4$ & - & $1 / 4$ \\
\hline
\end{tabular}

Second stage of the experimental study. The broilers that received 1\% Crotalaria lanceolata (Group E1) in the diet presented apathy, ruffled feathers and inappetence nine days after the end of the seed supply, and one chicken had a bulging abdomen and died fifteen days after the end of the feed supply. The broilers that received $\%$ C. lanceolata (Group E2) presented reduced feed intake, and one chicken died twelve days after the end of the seed supply. The primary gross lesions observed were ascites, hypertrophy, and yellowish liver, whereas the following microscopic lesions were verified: mainly swelling and vacuolar hepatocyte degeneration accompanied by megalocytosis and loss of cord architecture in hepatocytes (Fig.1). The gross and microscopic changes are described in Tables 5 and 6, respectively. The birds in the Control Group showed no clinical signs or pathological conditions. Analysis of the seed samples of the two Crotalaria species used in this study revealed presence of toxic pyrrolic esters or dehydropyrrolizidine alkaloids (DHPA). Total alkaloids were quantified from the dry weight of the samples. C. lanceolata presented $910 \mu \mathrm{g} / \mathrm{g}$ of toxic DHPA, i.e., $0.091 \%$ (dry weight), whereas Crotalaria pallida showed $737 \mu \mathrm{g} / \mathrm{g}$ of toxic DHPA, i.e., $0.0737 \%$ (dry weight).

\section{DISCUSSION}

This study verified that Crotalaria lanceolata seeds were toxic to broiler chickens that received, as of seven days of age, single doses of $15 \%$ and $25 \%$ and daily doses of $0.4 \%$, $0.8 \%$ and $2.5 \%$ in feed for 21 and 35 days, as well as to those that received, as of the age of 28 days, daily doses of $1 \%$ and $2 \%$ in feed for 20 days.

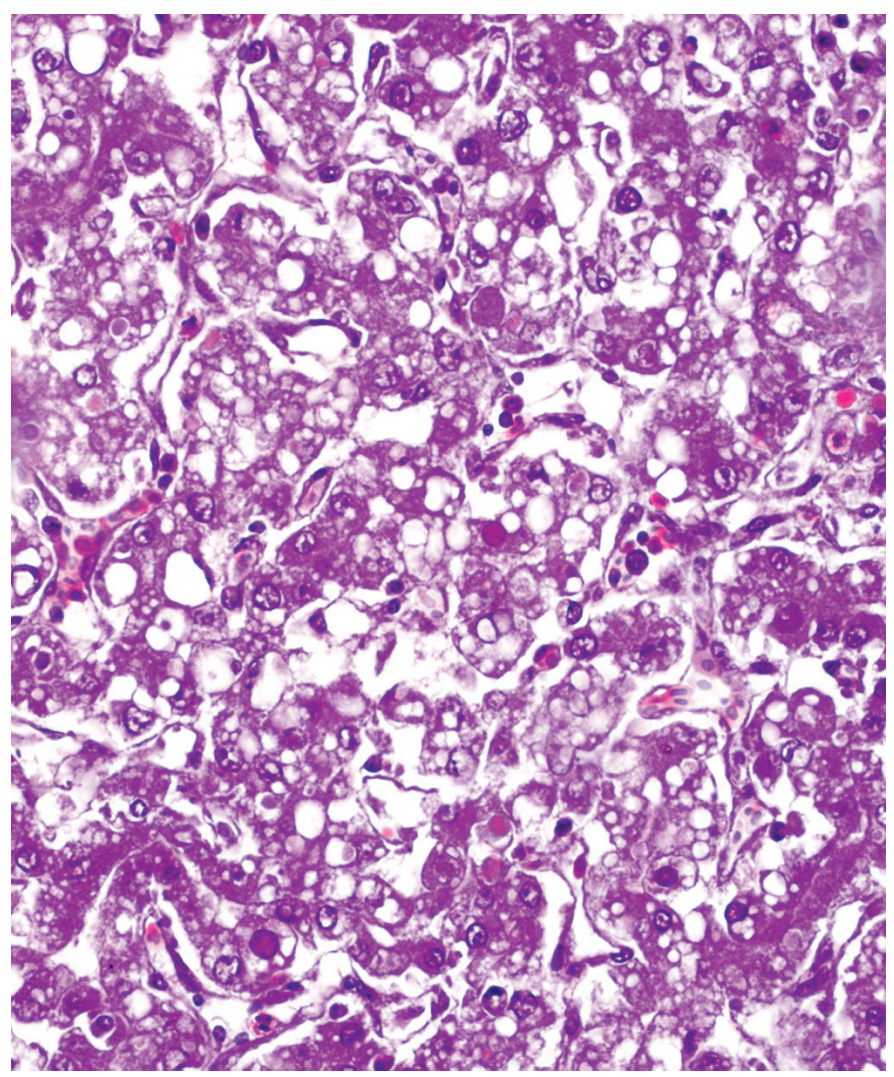

Fig.1. Experimental poisoning with $2 \%$ Crotalaria lanceolata seeds in the diet of broiler chickens (Group E2). Vacuolar degeneration, megalocytosis, cord architecture loss in hepatocytes, mild biliary proliferation, and hyaline spheres (arrows). HE, obj.40x. 
Table 6. Microscopic lesions observed in broilers euthanized at 80 days. Experimental poisoning by Crotalaria pallida and Crotalaria lanceolata seeds, $1 \%$ and $2 \%$ in the diet, Group D (1 and 2) and Group E (1 and 2)

\begin{tabular}{|c|c|c|c|c|}
\hline \multirow[b]{2}{*}{ Lesions } & \multicolumn{4}{|c|}{ Group } \\
\hline & $\begin{array}{c}\text { D1 } \\
\text { 1\% C. pallida }\end{array}$ & $\begin{array}{c}\text { D2 } \\
2 \% \text { C. pallida }\end{array}$ & $\begin{array}{c}\text { E1 } \\
1 \% \text { C. lanceolata }\end{array}$ & $\begin{array}{c}\text { E2 } \\
2 \% \text { C. lanceolata }\end{array}$ \\
\hline Pulmonary edema & - & - & ++ & - \\
\hline Vacuolar hepatocyte degeneration & - & - & + & ++ \\
\hline Hepatocyte megalocytosis & - & + & + & +++ \\
\hline Hepatocyte karyomegaly & - & - & + & + \\
\hline Hepatocyte swelling & + & ++ & + & ++ \\
\hline Biliary epithelium proliferation & - & - & + & + \\
\hline
\end{tabular}

Crotalaria pallida proved to be less toxic than C. lanceolata, and the doses that caused clinical changes and gross and microscopic lesions were as follows: single doses of $25 \%$ and daily doses of $0.8 \%$ and $2.5 \%$ in ration for 35 days. In broiler chickens aged 28 days, Crotalaria pallida seeds also showed toxicity at daily doses of $1 \%$ and $2 \%$ in feed for 20 days.

The following clinical changes were observed in some birds poisoned by both C. lanceolata and C. pallida: inappetence, ruffled feathers, and brownish diarrhea that arose from the second week of seed supply, as well as growth retardation. These changes, except for the diarrhea, have been previously observed in poisoning with Crotalaria spectabilis (Allen et al. 1960, Simpson et al. 1963, Hatayde et al. 1997a, 1997b, Pereira et al. 2011), with C. spectabilis and Crotalaria striata (C. pallida) (Bierer et al. 1960, Kelly et al. 1961), and with Crotalaria retusa (Hooper \& Scanlan 1977).

Gross lesions included subcutaneous edema, ascites, hydropericardium, yellowish liver with hypertrophy, atrophy (Allen et al. 1960, Simpson et al. 1963, Hatayde et al. 1997b, Pereira et al. 2011) and enhanced lobular pattern, and distended gallbladder (Hooper \& Scanlan 1977). These lesions were also observed in this study with both C. lanceolata and C. pallida; however, jaundice and bleeding in serosa and mucosa, as described by Figueredo et al. (1987) and Alfonso et al. (1993), were not verified.

The main microscopic lesions caused by $C$. lanceolata and C. pallida were similar but of varying intensity, and were more severe for C. lanceolata. Hepatocyte swelling, megalocytosis and vacuolar degeneration were also observed, and were similar to the lesions described for C. striata (C. pallida) (Bierer et al. 1960, Kelly etal. 1961). Loss of hepatocyte cord architecture was also observed in the present study. In the birds that presented gross liver lesions, eosinophilic spheroids or formation of Councilman hyaline bodies, marked megalocytosis and nuclear invagination were also observed, as described for Crotalaria mucronata (C. pallida) poisoning in cattle (Boghossian et al. 2007). Chromatin-thickening hepatocytes around the nuclear membrane have been frequently observed with enhanced and enlarged nucleoli, as described in bird poisoning by C. spectabilis seeds (Hatayde et al. 1997b, Pereira et al. 2011).

However, Pereira et al. (2011) also describe hepatic necrosis, bruising, connective tissue proliferation, and inflammatory infiltrate, which were not evidenced in this study. Fibrosis and proliferation of biliary epithelium in Crotalaria spp. seem to be more evident in the equine (Nobre et al. 2004a, 2004b), bovine (Nobre et al. 2004a) and ovine (Dantas et al. 2004,
Riet-correa et al. 2011) species. In the birds of the present study, these changes were slight, which can be attributed to their slaughter time after the end of the feed intake. A common feature observed in poisoning by C. lanceolata and C. pallida at single doses of $15 \%$ and $25 \%$ drew attention: gross liver lesions seemed to be regressive, since birds euthanized at 28 days of age showed histologic lesions such as swelling, vacuolar hepatocyte degeneration, cariomegaly, and nuclear invagination. These lesions were not observed in the birds that received the same doses and were euthanized at 42 days of age. The daily dose of $2.5 \%$ caused progressive lesions for both C. lanceolata and C. pallida poisoning.

Poisoning by green leaves or seeds of $C$. pallida has caused pneumotoxicity in cattle (Tokarnia \& Döbereiner 1982, Lemos et al. 1997, Boghossian et al. 2007). Acute clinical presentation of pulmonary edema was observed in sheep with gross and microscopic lesions restricted to the respiratory system. It was also found that non-lethal daily doses of $C$. pallida $(0.63$ and $1.25 \mathrm{~g} / \mathrm{kg})$ given to sheep for 30 days did not have cumulative effect, as they did not become ill (Borelli et al. 2016). It is worth noting that sheep are more resistant to PA than other species (Lucena et al. 2010). According to what was suggested by Pessoa et al. (2013), in the reproduction of liver and lung disease in donkeys, it is hypothesized that prolonged exposure to low levels of DHPA results in mild hepatotoxicity, and that lung lesions do not occur until the dose is sufficiently high for DHPA to be metabolized in the lung, or that pneumotoxic compounds pass intact through metabolism and are activated only in the lung, causing injury. In the present study, pulmonary lesions were not significant.

Crotalaria lanceolata seeds were 1.23 times more toxic than C. pallida seeds to the poultry assessed in this study, resembling the toxicity of $C$. retusa described by Hooper \& Scanlan (1977) and that of C. spectabilis reported by Pereira et al. (2011). Allen et al. (1960) reported that chickens poisoned with concentrations higher than $0.3 \%$ C. spectabilis seeds for 18 days reached $100 \%$ mortality. Chickens poisoned with $0.5 \%$ C. retusa seeds with monocrotaline concentration ranging from 4.0-4.4\% began to die in the beginning of seed supply and, at 45 days of age, all birds were dead (Hooper \& Scanlan 1977). Another previous study showed bird mortality by C. spectabilis at doses of $0.045 \%$ of seed fed to one-day chickens, $0.09 \%$ fed to four-week chickens, and $0.72 \%$ fed to turkeys, with the last resulting in $100 \%$ mortality (Simpson et al. 1963). Laying hens fed $0.02 \%, 0.04 \%$ and $0.06 \%$ seeds of $C$. spectabilis for 
28 days showed $5 \%, 25 \%$ and $40 \%$ mortality, respectively (Pereira et al. 2011). In experiments performed with C. pallida, Kelly et al. (1961) verified bird mortality as of the $4^{\text {th }}$ week of supplying $3 \%$ and $6 \%$ of seeds in the feed. Diaz et al. (2003) reported mortality of birds fed doses of $1 \%, 2 \%$ and $3 \%$ of seeds for 21 days. In this study, there were no deaths of birds poisoned by C. pallida, contrary to what was observed with birds poisoned by $1 \%$ and $2 \%$ C. lanceolata seeds. Difference in intensity of the lesions was observed between broiler chickens of the same group - a fact that may be associated with the difference in sensitivity between individuals and/or with feed selectivity regarding grain size.

Difference in toxicity between the aforementioned species may be associated with the type of DHPA and the amount present in its seeds, which may vary according to the time of year and even to desiccation (Hurst 1942) and storage time. The concentration of PA determines the plant toxicity and, consequently, the acute or chronic evolution of the poisoning condition. Monocrotaline, the most frequently PA isolated from plants of genus Crotalaria spp. causes pulmonary hypertension and right ventricular hypertrophy, which result from increased resistance to blood flow through the lungs caused by lung injury (Wilson et al. 1992, Pan et al. 1993). The main changes are pulmonary edema and congestion with consolidated areas in the parenchyma, causing interstitial and pulmonary arteriolar lesions, with inflammation, hemorrhage and fibrosis (Nobre et al. 1994). The PA isolated from C. pallida were millin, integerrimine, nilgirine, and crostastriatine (Smith \& Culvenor 1981), but there was no evidence of monocrotaline. In the study by Diaz et al. (2014), C. pallida seed analysis for DHPA content detected usaramine and its $\mathrm{N}$-oxide, in total alkaloid concentration of $0.18 \%$ (dry weight). In 1987 , Williams \& Molyneux isolated from a C. mucronata (C. pallida) sample a total amount of toxic alkaloids of $0.15 \%$. From a sample of C. lanceolata from Brazil, they quantified $0.21 \%$ of total toxic alkaloids, but did not identify them. In this study, the total alkaloid quantification for C. lanceolata presented $910 \mu \mathrm{g} / \mathrm{g}$ of toxic DHPA, i.e., $0.091 \%$ (dry weight), whereas C. pallida showed $737 \mu \mathrm{g} / \mathrm{g}$ of toxic DHPA, i.e., $0.0737 \%$ (dry weight). This difference in DHPA concentration may explain the lower severity of C. pallida lesions when compared with those of C. lanceolata.

\section{CONCLUSIONS}

Crotalaria lanceolata seeds were toxic to broiler chickens as of the 7 th day of life in single doses of $15 \%$ and $25 \%$ and daily doses of $0.4 \%, 0.8 \%$ and $2.5 \%$ in the feed for 21 and 35 days. In broilers aged 28 days, toxicity was also observed at the doses of $1 \%$ and $2 \%$ in the feed for 20 days.

Crotalaria pallida seeds were also toxic to broiler chickens, but to a lesser extent, at a single dose of $25 \%$ and at daily doses from $0.8 \%$ and $2.5 \%$ in the diet for 35 days.

The lesions caused to broilers by seeds of $C$. lanceolata and C. pallida are compatible with those caused by pyrrolizidine alkaloids, mainly affecting the liver.

Acknowledgments.- The authors are grateful to "Universidade do Estado de Santa Catarina" (UDESC) for supporting to this project, to CAPES for the scholarship granted, and to the Dr. Roseli Lopes Bortoluzzi for the botanical classification. We also would like to thank the Poisonous Plant
Research Laboratory, ARS, USDA, in Logan, Utah, USA for the quantification of pyrrolizidine alkaloids in seeds.

Conflict of interest statement.- The authors declare having no competing interests.

\section{REFERENCES}

Alfonso H.A., Sanchez L.M., Figueredo M. de Los Angeles \& Gomez B.C. 1993. Intoxication due to Crotalaria retusa and C. Spectabilis in chickens and geese. Vet. Human Toxicol. J. 35:539-544.

Allen J.R., Childs G.R. \& Cravens W.W. 1960. Crotalaria spectabilis toxicity in chickens. Proc. Soc. Exp. Biol. Med. 104:434-436.

Anjos B.L., Nobre V.M.T., Dantas A.F.M., Medeiros R.M.T., Oliveira Neto T.S., Molyneux R.J. \& Riet-Correa F. 2010. Poisoning of sheep by seeds of Crotalaria retusa: acquired resistance by continuous administration of low doses. Toxicon 55(1):28-32. <http://dx.doi.org/10.1016/j.toxicon.2009.06.028> <PMid:19576921>

Bierer B.W., Vickers C.L., Rhodes W.H. \& Thomas J.B. 1960. Comparison of the toxic effects of Crotalaria spectabilis and Crotalaria giant striata as complete feed contaminants. J. Am. Vet. Med. Assoc. 136:318-322. <PMid:13800572>

Boghossian M.R., Peixoto P.V., Brito M.F. \& Tokarnia C.H. 2007. Aspectos clínico-patológicos da intoxicação experimental pelas sementes de Crotalaria mucronata (Fabaceae) em bovinos. Pesq. Vet. Bras. 27(4):149-156. <http:// dx.doi.org/10.1590/S0100-736X2007000400004>

Borelli V., Cardoso T.C., Biffi C.P., Wicpolt N., Ogliari D., Savari T., Traverso S.D. \& Gava A. 2016. Intoxicação experimental por folhas de Crotalaria pallida (mucronata) em ovinos. Pesq. Vet. Bras. 36(10):935-938. <http://dx.doi. org/10.1590/s0100-736x2016001000003>

Cheeke P.R. 1998. Natural Toxicants in Feeds, Forages and Poisonous Plants. 2nd ed. Interstate Publishers, Danville, CA. 479p.

Dantas A.F.M., Nobre V.M.T., Riet-Correa F., Tabosa I.M., Júnior G.S., Medeiros J.M., Silva R.M.N., Silva E.M.N., Anjos B.L. \& Medeiros J.K.D. 2004. Intoxicação crônica espontânea por Crotalaria retusa (Fabaceae) em ovinos na região do semiárido Paraibano, Brasil. Pesq. Vet. Bras. 24(Suppl.):18-19.

Diaz G.J., Almeida L.X. \& Gardner D.R. 2014. Effects of dietary Crotalaria pallida seeds on the health and performance of laying hens and evaluation of residues in eggs. Res. Vet. Sci. J. 97(2):297-303.<http://dx.doi.org/10.1016/j. rvsc.2014.06.011><PMid:25062989>

Diaz G.J., Roldán L.P. \& Cortés A. 2003. Intoxication of Crotalaria pallida seeds to growing broiler chicks. Vet. Human Toxicol. 45(4):187-189. <PMid:12882487>

Figueredo M.L.A., Rodrigues I. \& Alfonso H.A. 1987. Patomorfologia de la intoxicacion experimental aguda por Crotalaria retusa y Crotalaria spectabilis em pollos. Revta Cubana Ciênc. Vet. 18(112):63-71.

Flores A.S. 2015. Crotalaria L. Lista de Espécies da Flora do Brasil, Jardim Botânico do Rio de Janeiro, Rio de Janeiro. Available at <http://floradobrasil. jbrj.gov.br/jabot/floradobrasil/FB22902> Accessed on Jan. 17, 2015.

Fu P.P., Xia Q., Lin G. \& Chou M.W. 2004. Pyrrolizidine alkaloids: genotoxicity, metabolism enzymes, metabolic activation and mechanisms. Drug Metabol. Rev. 36(1):1-55. <http://dx.doi.org/10.1081/DMR-120028426> <PMid:15072438>

Garcia J.M., Kawakita K., Miotto S.T.S. \& Souza M.C. 2013. 0 gênero Crotalaria L. (Leguminosae, Faboideae, Crotalarieae) na planície de inundação do Alto Rio Paraná, Brasil. Revta Bras. Biociênc. 11(2):209-226.

Hatayde M.R., Berchieri Junior A., Alessi A.C. \& Curtarelli S.M. 1997a. Estudo experimental sobre a intoxicação de Gallus gallus domesticus com sementes de Crotalaria spectabilis. I - Efeito em aves na fase inicial de crescimento. Braz. J. Vet. Res. Anim. Sci. 34(6):332-336.

Hatayde M.R., Berchieri Junior A., Alessi A.C. \& Curtarelli S.M. 1997b. Estudo experimental sobre a intoxicação de Gallus gallus domesticus com sementes 
de Crotalaria spectabilis. II - Efeito em aves na fase final de crescimento. Arq. Bras. Med. Vet. Zootec. 49(2):239-249.

Hooper P.T. \& Scanlan W.A. 1977. Crotalaria retusa poisoning of pigs and poultry. Austr.Vet. J.53(3):109-114.<http://dx.doi.org/10.1111/j.1751-0813.1977. tb00129.x $><$ PMid:869796>

Hurst E. 1942. The Poison Plants of New South Wales. N.S.W. Poison Plants Committee, Sidney, p.155-158.

Kelly J.W., Barber C.W., Pate D.D. \& Hill C.H. 1961. Effect of feeding Crotalaria seed to young chickens. J. Am. Vet. Med. Assoc. 139(11):1215-1217. <PMid:14455016>

Lemos R.A.A., Dutra I.S., Souza G.F., Nakazato L. \& Barros C.S.L. 1997. Intoxicação espontânea por Crotalaria mucronata em bovinos em Minas Gerais. Arqs Inst. Biológico, São Paulo, 64(Suppl.):46.

Lucena R.B., Rissi D.R., Maia L.A., Flores M.M., Dantas A.F.M., Nobre V.M.T., RietCorrea F. \& Barros C.S.L. 2010. Intoxicação por alcaloides pirrolizidínicos em ruminantes e equinos no Brasil. Pesq. Vet. Bras. 30(5):447-452.<http:// dx.doi.org/10.1590/S0100-736X2010000500013>

Nobre D., Dagli M.L.Z. \& Haraguchi M. 1994. Crotalaria juncea intoxication in horses. Vet. Human Toxicol. J. 36(5):445-448. <PMid:7839571>

Nobre V.M.T., Riet-Correa F., Barbosa Filho J.M., Tabosa I.M. \& Vasconcelos J.S. 2004a. Intoxicação por Crotalaria retusa (Fabaceae) em eqüídeos no semiárido da Paraíba. Pesq. Vet. Bras. 24(3):132-143. <http://dx.doi. org/10.1590/S0100-736X2004000300004>

Nobre V.M.T., Riet-Correa F., Dantas A.F.M., Tabosa I.M., Medeiros R.M.T. \& Barbosa Filho J.M. 2004b. Intoxication by Crotalaria retusa in ruminants and equidae in the state of Paraíba, Northeaster Brazil, p.275-279. In: Acamovich T., Stewart C.S. \& Pennycott T.W. (Eds), Plant Poisoning and Related Toxins. CAB International, Glasgow. <http://dx.doi.org/10.1079/9780851996141.0275>

Nobre V.M.T., Dantas A.F.M., Riet-Correa F., Barbosa Filho J.M., Tabosa I.M. \& Vasconcelos J.S.V. 2005. Acute intoxication by Crotalaria retusa in sheep. Toxicon 45(3):347-352. <http://dx.doi.org/10.1016/j.toxicon.2004.11.005> <PMid:15683873>

Pan L.C., Wilson D.W., Lamé M.W., Jones A.D. \& Segall H.J. 1993. Cor pulmonale is caused by monocrotaline and dehydromonocrotaline, but not by glutathione or cysteine conjugates of dehydropyrrolizidine. Toxicol. Appl. Pharmacol. 118(1):87-97.<http://dx.doi.org/10.1006/taap.1993.1013> $<$ PMid:8430429>

Pereira W.A.B., Hatayde M.R., Godoy G.S., Alessi A.C. \& Berchieri Junior A. 2011. Clinical and pathological changes of laying hens (Gallus gallus domesticus) experimentally poisoned by Crotalaria spectabilis seeds (Leg. Papilionoideae). Ars Vet. 27:45-50.

Pessoa C.R.M., Pessoa A.F.A., Maia L.A., Medeiros R.M.T., Colegate S.M., Barros S.S., Soares M.P., Borges A.S. \& Riet-Correa F. 2013. Pulmonary and hepatic lesions caused by the dehydropyrrolizidine alkaloid-producing plants
Crotalaria juncea and Crotalaria retusa in donkeys. Toxicon 71:113-120. <http://dx.doi.org/10.1016/j.toxicon.2013.05.007> <PMid:23726858>

Queiroz G.R., Ribeiro R.C.L., Flaiban K.K.M.C., Bracarense A.P.F.R.L. \& Lisbôa J.A.N. 2013. Intoxicação espontânea por Crotalaria incana em bovinos no norte do estado do Paraná. Semina, Ciênc. Agrárias 34(2):823-832. <http:// dx.doi.org/10.5433/1679-0359.2013v34n2p823>

Riet-Correa F., Carvalho K.S., Dantas A.F.M. \& Medeiros R.M.T. 2011. Spontaneous acute poisoning by Crotalaria retusa in sheep and biological control of this plant with sheep. Toxicon 58(6/7):606-609. <http://dx.doi.org/10.1016/j. toxicon.2011.09.002 > <PMid:21930140>

Simpson C.F., Waldroup P.W. \& Harms R.H. 1963. Pathologic changes associated with feeding various levels of Crotalaria spectabilis seeds to poultry. J. Am. Vet. Med. Assoc. 142(3):264-271. <PMid:13977554>

Smith L.W. \& Culvenor C.C.J. 1981. Plant sources of hepatotoxic pyrrolizidine alkaloids. J. Nat. Prod. 44(2):129-152. <http://dx.doi.org/10.1021/ np50014a001><PMid:7017073>

Souza A.C., Hatayde M.R. \& Berchara G.H. 1997. Aspectos patológicos da intoxicação de suínos por sementes de Crotalaria spectabilis (Fabaceae). Pesq. Vet. Bras. 17(1):12-18. <http://dx.doi.org/10.1590/S0100736X1997000100003>

Tokarnia C.H. \& Döbereiner J. 1982. Intoxicação experimental por Crotalaria mucronata (Leg. Papilionoideae) em bovinos. Pesq. Vet. Bras. 2(2):77-85.

Tokarnia C.H. \& Döbereiner J. 1983. Intoxicação experimental por Crotalaria anagyroides (Leg. Papilionoideae) em bovinos. Pesq. Vet. Bras. 3(4):115-123.

Tokarnia C.H., Döbereiner J. \& Peixoto P.V. 2012. Plantas Tóxicas do Brasil. Ed. Helianthus, Rio de Janeiro. 310p.

Torres M.B.A.M., Salles M.W.S., Headley S.A. \& Barros C.L.S. 1997. Intoxicação experimental por sementes de Crotalaria spectabilis (Leguminosae) em suínos. Ciência Rural 27(2):307-312.<http://dx.doi.org/10.1590/S010384781997000200023>

Ubiali D.G., Boabaid F.M., Borges N.A., Caldeira F.H.B., Lodi L.R., Pescador C.A., Souza M.A. \& Colodel E.M. 2011. Intoxicação aguda com sementes de Crotalaria spectabilis (Leg. Papilionoideae) em suínos. Pesq. Vet. Bras. 31(4):313-318. <http://dx.doi.org/10.1590/S0100-736X2011000400007>

Wiedenfeld H. \& Edgar J. 2011. Toxicity of pyrrolizidine alkaloids to humans and ruminants. Phytochem. Rev. 10(1):137-151.<http://dx.doi.org/10.1007/ s11101-010-9174-0>

Williams M.C. \& Molyneux R.J.1987. Occurrence, concentration, and toxicity of pyrrolizidine alkaloids in Crotalaria seeds. Weed Science 35(4):476-481. <http://dx.doi.org/10.1017/S0043174500060410>

Wilson D.W., Segall H.J., Pan L.C., Lamé M.W., Estep J.E. \& Morin D. 1992. Mechanisms and pathology of monocrotaline pulmonary toxicity. Crit. Rev. Toxicol. 22(5-6):307-325. <http://dx.doi.org/10.3109/10408449209146311> $<$ PMid:1489509> 